\title{
Professional learning for 21st century education
}

\author{
Ching Sing Chai ${ }^{1} \cdot$ Siu-Cheung Kong ${ }^{1}$
}

Received: 30 May 2016/ Accepted: 14 June 2016/Published online: 13 July 2016

(C) Beijing Normal University 2016

The emergence of the current technology-driven world has raised many challenges to didactic teaching and learning in traditional classrooms. Couple with volatile, uncertain, complex, and ambiguous (VUCA) characteristics of current society (Bennett and Lemoine 2014), both what is to be learned and how learning or knowledge construction should happen need serious reconceptualization. The notion of 21 st century learning can be viewed as an overarching vision of education that many educators are now advocating as a collective response to the challenges. Key dimensions of learning practices promoted by various 21 st century learning models include collaborative learning, use of ICT as tools for knowledge construction and co-construction, critical and creative thinking, and authentic problem solving (Chai et al. 2015; Dede 2010; Howland et al. 2012; Voogt and Roblin 2012). Beyond these practices, some models also concern citizenship education. Despite the consensus that has been developed, schools, however, may not have changed as much as desired (Voogt et al. 2013). Other education and training organizations may be more sensitive to respond to the VUCA situations, and they are nonetheless searching for appropriate ways to educate their employees.

Professional development for the educators has always been the key enabling factor for transformation in education to happen. To develop the educators' competencies for 21 st century teaching and learning, many aspects have to be looked into. These include the knowledge, beliefs, and most recently the design capacities of the educator (Tsai and Chai 2012). Professional development for educators involves transforming their knowledge into practice for the benefit of their

Siu-Cheung Kong

sckong@eduhk.hk

1 Department of Mathematics and Information Technology, The Education University of Hong Kong, 10 Lo Ping Road, Tai Po, New Territories, Hong Kong 
learners. It has been advocated that professional learning community is a viable way for educators to experience co-constructing knowledge to experience the transformative change needed (Kong and Song 2013).

This special issue brings together a total of five papers that address current issues for 21 st century-oriented education. The overall theme that emerges from the five articles apparently points to the necessity of adaptive expertise directed toward solving emerging problems (Bransford et al. 1999). Instead of providing information for learners, professional learning in the 21st century is about employing existing knowledge to frame emerging phenomena and create and test new knowledge to see if they could engage the phenomena in a meaningful way. We briefly summarize the themes of the articles below.

The first paper by Kong et al. (2016) review how Hong Kong, Singapore, Taiwan, and China attempt to promote e-learning among teachers. Singapore and Hong Kong are geographically small though economically strong entities. Their responses toward e-learning emphasize much on teachers' learning in community. Taiwan, on the other hand, is one of the areas where educational research is very vibrant, supported by many distinguished professors. The Taiwanese teachers therefore enjoy close collaboration with university professors. Lastly, with its vastly huge territory and diverse populations, China has opted to provide self-directed e-learning as a means to promote teachers' learning. While the approaches are different, these areas in Asia are nonetheless all devoted to promote teachers professional development for the 21 st century.

The second and third paper focuses on employing the knowledge building approach to foster knowledge creation among learners. Chen and Hong's (2016) recent review indicated that it is important to transform schools into knowledge building organizations. The second paper (Wong et al. 2016) reveals the challenges that teachers may face when they are engaged in changing classroom to knowledge building communities. Instead of converting content knowledge through pedagogical means so that they are accessible to students, teachers in knowledge building environment encourage students to construct understanding themselves. Guiding students' sense-making processes is highly discursive and it demands teachers' to ask appropriate questions. Such adaptive expertise would require teachers' to develop ability to orchestrate learning rather than deliver information in a control environment. The third paper by Lin et al. (2016) documents their effort in promoting college students' creative capacity. Such capacity is vital for their longterm employability in the VUCA society. The two papers in knowledge building indicate the vitality of the knowledge building approach even though the model has evolved over thirty years.

The fourth paper by Lim (2016) proposes the notion of disciplinary intuition for the professional development of security personal. Professional learning that fosters adaptive disposition is essential for security personnel as well as other professionals. The lack of adaptive disposition implies a mode of learning that assumes that the world is unchanging and what is known is sufficient. Nothing is further from the truth and the inclusion of this article is aimed at broadening educators' perspective on the possible ways forward. 
Lastly, Maor's (2016) article dwells on the design of e-learning employing the technological pedagogical content knowledge (TPACK) as a framework. The TPACK framework has emerged as a theoretical framework to generate and consolidate the knowledge needed by teachers in order to create ICT-integrated lessons. It is a relatively young framework with much potential, and it focuses on knowledge and knowing concurrently, implying that it is not sufficient for teachers to learn from best practice given the dynamic nature of technology advancement.

Overall, these articles point out the importance to equip education professionals with capacities to deal with emerging challenges. Needless to say, many more research are needed to foster such capacities. It is apparent that engaging educators in design-based or design-oriented learning has emerged as a main approach forward.

\section{References}

Bennett, N., \& Lemoine, J. (2014). What VUCA really means for you. Harvard Business Review, 92(1/2). Bransford, J. D., Brown, A. L., \& Cocking, R. R. (1999). How people learn: Brain, mind, experience, and school. Washington, DC: National Academy Press.

Chai, C. S., Deng, F., Tsai, P.-S., Koh, J. H. L., \& Tsai, C.-C. (2015). Assessing multidimensional students' perceptions of twenty-first-century learning practices. Asia-Pacific Education Review, 16(3), 389-398.

Chen, B., \& Hong, H.-Y. (2016). Schools as knowledge-building organizations: Thirty years of design research. Educational Psychologist, 51(2), 266-288. doi:10.1080/00461520.2016.1175306.

Dede, C. (2010). Comparing frameworks for 21 st century skills. 21st century skills Rethinking how students learn, 20, 51-76.

Howland, J. L., Jonassen, D. H., \& Marra, R. M. (2012). Meaningful learning with technology. Upper Saddle River: Pearson.

Kong, S.-C., Looi, C. K., Chan, T.-W., \& Huang, R. H. (2016). Teacher development in Singapore, Hong Kong, Taiwan and Beijing for e-learning in school education. Journal of Computers in Education. doi:10.1007/s40692-016-0062-5.

Kong, S. C., \& Song, Y. (2013). A principle-based pedagogical design framework for developing constructivist learning in a seamless learning environment: A teacher development approach for learning and teaching in digital classrooms in school education. British Journal of Educational Technology, 44(6), E209-E212.

Lim, K. Y. T. (2016). Nurturing an adaptive disposition in the context of security training through the approach of disciplinary intuitions. Journal of Computers in Education. doi:10.1007/s40692-0160060-7.

Lin, P.-Y., Chang, Y.-H., Lin, H.-T., \& Hong, H.-Y. (2016). Fostering college students' creative capacity through computer-supported knowledge building. Journal of Computers in Education. doi:10.1007/ s40692-016-0063-4.

Maor, D. (2016). Using TPACK to develop digital pedagogues: A higher education experience. Journal of Computers in Education. doi:10.1007/s40692-016-0055-4.

Tsai, C.-C., \& Chai, C. S. (2012). The "third"-order barrier for technology-integration instruction: implications for teacher education. Australasia Journal of Education Technology, 28(6), 1057-1060.

Voogt, J., Knezek, G., Cox, M., Knezek, D., \& ten Brummelhuis, A. (2013). Under which conditions does ICT have a positive effect on teaching and learning? A call to action. Journal of Computer Assisted learning, 29(1), 4-14.

Voogt, J., \& Roblin, N. P. (2012). A comparative analysis of international frameworks for 21st century competences: implications for national curriculum policies. Journal of Curriculum Studies, 44(3), 299-321. 
Wong, A., Chai, C. S., \& Hairon, S. (2016). Exploring the impact of teacher experience on questioning techniques in a Knowledge Building classroom. Journal of Computers in Education. doi:10.1007/ s40692-016-0057-2.

Chai Ching Sing is an Associate Professor in the Learning Sciences and Technologies Academic Group at National Institute of Education, Nanyang Technological University (NIE/NTU), Singapore since 2001. Before he joined NIE, he was a Head of Department in a secondary school. He is the Doctoral Program Coordinator of LST. He obtained his BA degree from the National Taiwan University under the sponsorship of PSC Oversea Tenable Scholarship. He completed his MA degree in NIE in 2001 and his doctoral study in 2006.

Siu-Cheng Kong is a Professor of Department of Mathematics and Information Technology and Director of Centre for Learning, Teaching, and Technology at The Education University of Hong Kong. He was the Convener of Theory and Practice of Pedagogical Design for Learning in Digital Classrooms International Research Network (IRN) under World Educational Research Association (WERA) from December 2012 to December 2015. His research interests include pedagogy in digital classroom, IT in mathematics education, information literacy education, and policy, practice, and research in technology transformed education. 